\title{
Credit Reference Agencies
}

\section{How do they work?}

\section{Information about:}

- credit reference agencies

- the information on files about you

- correcting mistakes

- credit scoring.

\section{The Co-operative Bank and responsible lending}

The Co-operative Bank is proud of its reputation as a responsible lender. Whilst we want to help individuals to buy the things they can afford, we do not want them to take on so much credit that the repayments will be too high for them to manage.

When you apply to open an account with us we have to decide if you appear to be an acceptable credit risk. To do that, we use a variety of information:

- the details you have given us on the application form

- how you have operated your accounts in the past

- information from one or more Credit Reference Agencies that we use.

The application is only approved if all the information we receive is acceptable. We use a method called credit scoring to assess applications to open an account or borrow money, although our decision is not necessarily based on credit score alone.

This leaflet therefore explains in more detail about credit reference agencies and credit scoring, how the information credit reference agencies provide is used to approve or decline an application, and how you can change inaccurate or incomplete information which they may hold about you.

\section{What is a Credit Reference Agency?}

Credit Reference Agencies are companies which hold information on computers on just about every adult in the United Kingdom. Typically, this information will include:

- your address

- records of any County Court Judgements and bankruptcies

- previous and existing credit accounts.

Credit Reference Agencies do not keep 'blacklists' of people who are poor credit risks nor do they give any opinion about whether or not you should be given credit. They simply provide basic factual information. The bank makes the final decision.

\section{Where do Credit Reference Agencies get their information from?}

Credit Reference Agencies obtain information from:

- The electoral voters roll. This helps to show whether or not you live at the address you have given 
- County Court judgements. The Credit Reference Agency collects the public records of all people taken to court for not paying their debts. The judgements (called decrees in Scotland) are normally kept for six years. A court can remove judgement information from the records if the debt is fully repaid within one month of judgement. A court can also register the debt as satisfied when the debt has been fully repaid

- Bankruptcies. Again, the Credit Reference Agencies collect public records of bankruptcies. These may be kept for more than six years but you can ask the Credit Reference Agency to record that they have been discharged

- Previous and existing credit accounts. This information is supplied by lenders such as banks, other financial institutions, retail account providers and mail order companies. Much of the information Credit Reference Agencies hold is positive and shows that most people manage their credit commitments well. A history of paying on time is likely to help you get further credit.

\section{How do I know which Credit Reference Agencies the bank has used?}

The Credit Reference Agencies the bank may have used are detailed on the next page of this leaflet.

\section{How can I find out what the Credit Reference Agencies said about me?}

You can contact the Credit Reference Agencies at any time to ask for a copy of your statutory credit report. You will find contact details for all three agencies the bank regularly use on the back page of this leaflet. There will be a fee for this service.

When applying for your file you will need to provide:

- any other addresses you have lived at during the previous six years

- if you run a business, include its name and address too. The agency may hold separate information about you

- if you applied jointly you will each need to contact the Credit Reference Agency.

The agency will then send you your file within seven working days, unless it needs further information to identify you.

\section{Can I amend the information on my file?}

If the details on your file are correct, you cannot expect the agency to remove them just because they may be embarrassing. However the Credit Reference Agency may hold information about you which you believe is incorrect. To change incorrect information you should contact the agency and ask them to remove or amend your entry. The agency will usually add a marker to the disputed information to show that you have queried it, while it contacts the provider(s) on your behalf. The agency should reply within 28 days.

If the agency does not reply or writes to say that it will not change your entry, you have a further 28 days to send it a notice of correction. This is a statement of up to 200 words giving your side of the story. If the agency feels your statement is unsuitable, perhaps because it thinks it may be incorrect or defamatory, it will usually help you reword a more suitable alternative. If you insist on adding your original statement the agency will refer the matter to the Information Commissioner for a final decision. The agency can reject your notice if it feels it is right to do so.

Please note that if the incorrect information relates to an account with a bank, building society, retail account provider, or other credit grantor, the Credit Reference Agency cannot amend it without their permission. It is often quicker to write directly to the credit grantor concerned, asking them to amend the information. If the account concerned is a Co-operative Bank account you should write to our Customer Feedback section, enclosing a copy of the file you have obtained from the Credit Reference Agency. The address is on the next page of this leaflet.

The Credit Reference Agencies may hold information about people with whom you have a financial association, such as someone you have an account with, or may have made an application for credit with. Your credit report will specify any financial associations that you have. This information may be considered in making our decision, even if they are not applying jointly with you. If your credit report shows a financial connection that is no longer correct, you can request a financial disassociation, which means lenders will no longer see information about these other people when you apply for credit. To do this you should contact the Credit Reference Agency which supplied your file.

\section{What do I do if an agency will not amend my file?}

If a Credit Reference Agency refuses to add your notice of correction and you cannot agree upon an alternative, it will refer the matter to the Information Commissioner for a final decision. If the agency does not reply within 28 days of receiving your notice, you can contact the Information Commissioner yourself. The address is on the back page of this leaflet. 
When writing to the Information Commissioner, you should state that you are writing under section 159(5) of the Consumer Credit Act 1974. Confirm that you have followed all necessary steps within the time limit and have not heard from the agency.

Provide details of your notice and all relevant dates. It is also a good idea to enclose copies of any correspondence.

The Information Commissioner will make the final decision within two months of receiving information from both parties.

\section{What is credit scoring?}

Credit scoring is a method used by banks and other lenders to help them assess applications to open an account or borrow money.

It involves awarding points based on the information provided by you on your application form and from information obtained from one or more Credit Reference Agencies. This information will relate to yourself and possibly other individuals you may be financially linked to, such as someone you have an account with, or may have made an application for credit with. If you are already a Co-operative Bank customer, we may also add or subtract points depending on how you have managed your account(s). The points you are awarded are added together to produce your credit score. This is therefore an indication whether or not you are an acceptable risk. Credit Reference Agencies do not keep information on your credit score.

\section{The Credit Reference Agencies}

\section{Experian}

PO Box 9000, Nottingham NG80 7WP

Tel: 08444818000

www.experian.co.uk

\section{Equifax Credit File Advice Centre}

PO Box 1140,

Bradford BD1 5US

Tel: 08443350550

www.equifax.co.uk

\section{Callcredit Ltd}

One Park Lane, Leeds

West Yorkshire LS3 1EP

Tel: 08700601414

www.callcredit.co.uk

\section{Information Commissioner's Office}

Wycliffe House, Water Lane

Wilmslow SK9 5AF

Tel: 01625545745

www.ico.gov.uk

\section{Co-operative Bank Customer Feedback}

The Manager, Customer Feedback

The Co-operative Bank p.I.c., Miller Street, 4th Floor

Manchester M60 OAL

\section{Please call $03457212212^{*}$ (6am - 10pm 7 days a week) if you would like to receive this information in an alternative format such as large print, audio or Braille.}

The Co-operative Bank p.l.c. is authorised by the Prudential Regulation Authority and regulated by the Financial Conduct Authority and the Prudential Regulation Authority (No.121885). The Co-operative Bank, Platform, smile and Britannia are trading names of The Co-operative Bank p.l.c., P.O. Box 101, 1 Balloon Street, Manchester M60 4EP. Registered in England and Wales No.990937. Credit facilities are provided by The Co-operative Bank p.l.c. and are subject to status and our lending policy. The Bank reserves the right to decline any application for an account or credit facility. The Co-operative Bank p.l.c. subscribes to the Standards of Lending Practice which are monitored by the Lending Standards Board.

${ }^{*}$ Calls to 0800 and 0808 numbers are free from landlines and mobiles. Calls to 03 numbers cost the same as calls to numbers starting with 01 and 02 . Calls to 0845 and 0870 numbers cost $3 p$ per minute, plus your phone company's access charge. Calls to 0844 and 0843 numbers cost $7 p$ per minute, plus your phone company's access charge. Calls may be monitored or recorded for security and training purposes. 